\title{
Judeo-Christian civilizationism:
}

\section{challenging common European}

foreign policy in the Israeli-

\section{Palestinian arena}

\section{Mediterranean Politics}

\section{Dr. Toby Greene ${ }^{1}$}

Leonard Davis Institute for International Relations,

Hebrew University of Jerusalem,

Jerusalem,

Israel

Email for correspondence: toby@ tobygreene.net

ORCiD: https://orcid.org/0000-0002-4185-6281

LinkedIn: https://www.linkedin.com/in/tobygreene/

Twitter: @toby_greene_

This work was supported by a post-doctoral fellowship of the Israel Institute; and the European Union's Horizon 2020 research and innovation programme under the Marie Skłodowska-Curie grant agreement No 845179.

\footnotetext{
${ }^{1}$ The initial version of this paper was mostly prepared whilst the author was at the Leonard Davis Institute for International Relations, Hebrew University of Jerusalem. His affiliation as of July 2019 is Marie Skłodowska-Curie Research Fellow, School of Politics and International Relations, Queen Mary University of London, Mile End Road, London E1 4NS.
} 


\begin{abstract}
The EU's identity is said to shape its role as a 'normative actor' promoting universal democratic values, including to its neighbourhood. Yet a competing civilizationist version of European identity - increasingly invoked on the radical right - frames Europe as representing 'Judeo-Christian' values in opposition to non-European cultures, especially Islam. This paper argues that these identity variations shape divergent responses to foreign policy challenges, by showing the growing influence of civilizationist discourse on European attitudes towards the Israeli-Palestinian arena. The paper focuses on Austria’s 2017-2019 ÖVP-FPÖ coalition to identity links between rising civilizationist politics and significant policy shifts regarding the Israeli-Palestinian arena.
\end{abstract}

\title{
Keywords
}

civilizational identity, Austria, European Foreign Policy, Israeli-Palestinian conflict, populism, role theory 


\section{Judeo-Christian civilizationism: challenging common European foreign policy in the Israeli-Palestinian arena}

\section{Introduction}

This article contributes to the study of how the rise of populism affects the foreign policy of the EU and its members. It considers in particular the impact of rising, radical civilizationist interpretations of European identity on the EU's capacity to pursue a unified foreign policy in the Israeli-Palestinian arena. Though no wider generalizations can be affirmed solely from the singular case study presented, it suggests how civilizational identity politics may undermine any normative consensus about the EU's identity and broader international role.

Whilst EU institutions assert a 'secular-liberal' European identity based on religious neutrality (Wolff, 2018, p. 171), this conception of Europe is increasingly challenged. Analysing divides over European identity, Risse differentiates between an 'EU Europe ... embracing modern, democratic, and humanistic values' and a rival conception of 'a Europe of white Christian peoples that sees itself as a distinct civilization' (Risse, 2010, p. 6).

I refer to this latter version as 'civilizationism', and emphasise how the concept of 'JudeoChristian' is increasingly invoked interchangeably with 'Christian' on the populist radical right, when referring to the cultural common ground of European peoples. I argue that variations in identity construction shape variations in national role conception and foreign policy preferences among member states, inhibiting the unanimity required to harmonize diplomatic action.

The Israeli-Palestinian conflict has long tested EU foreign policy capacity. In the EU Foreign Affairs Council (FAC) member states span a spectrum of positions shaped by interests, and historically and culturally driven identity variations. Simultaneously a transnational split sees centre-right parties typically more sympathetic to Israel, and left leaning parties to the Palestinians.

Divergences have been repeatedly exposed in recent years, exacerbated by the collapse of the peace process and the dominance of the Israeli right, the support provided to Netanyahu by the Trump administration, and Israel's growing significance as a strategic ally for some (Greene and Rynhold, 2018). But they have also been exacerbated, I argue, by a growing transnational identity cleavage between 'civilizational' and 'universal' Europe. 
Drawing on role theory, I argue that civilizationist identity politics prompts role conceptions that vary from those defined by EU treaties: less a global mission promoting human rights and rule of law, and more a mission to defend Europe's civilizational heritage from Islamic threats. Those adopting this world view increasingly include Jews within Europe's cultural boundaries and identify Israel as Europe's front line.

I begin by presenting theoretical context on the significance of identity in EU foreign policy, as well as the broader relationship between identity and foreign policy as described by role theory. I then give an account of the rise of Judeo-Christian civilizationism in European political culture, before describing its growing role in framing the Israeli-Palestinian arena. In order to explore more deeply the relationship between civilizationist identity and policy preferences of individual states, I then present the case of Austria's 2017-2019 coalition between the Christian democratic Austrian People's Party (ÖVP) and the radical right Freedom Party (FPÖ), drawing on original in-depth interviews with senior officials and experts. The conclusion considers the implications for EU foreign policy beyond the IsraeliPalestinian arena.

\section{Europe's global role in question}

It is widely recognised that the EU's aspiration to be a significant international actor is compromised by enduring divergences among member states.

The creation of the High Representative and the European External Action Service reflected the aspiration of members for a stronger capacity to advance shared goals defined in EU treaties, including: encouraging regional cooperation and integration; promoting human rights, democracy and governance; and preventing conflicts (Smith, 2014, p. 2). The motivation for common foreign policy has various drivers. Economic integration necessarily drives integration of trade and other economic policies. Regarding diplomatic or military tools, the logic of scale implies that EU members are more effective in unison. The normative dimensions of EU goals stem from the EU's institutional role pacifying a Europe shattered by extreme nationalism and a desire to promote its successful model regionally and internationally; and from European states' strengths as civilian rather than military powers.

Constructivist approaches to European integration emphasise that a common foreign policy not only projects EU preferences and norms externally, but is 'an important practice of European identity construction' (Diez, 2005). Conversely, the lack of a strong shared 
European identity is an underlying weakness in formulating effective common foreign policy (Hill \& Wallace, 1996).

The intergovernmental method, and especially the Council of the EU, remains dominant in the use of diplomatic and military tools governed by the Common Foreign and Security Policy. Individual members retain effective veto over collective action, making the study of foreign policy attitudes within states enduringly relevant to EU foreign policy. The treaties aspire to 'an ever-increasing degree of convergence of Member States action' but members ultimately retain sovereignty over foreign policy (Keukeleire \& Delreux, 2014, p. 158). Differences are rooted not only in divergences of interests, but national identity and political culture. The Europeanization of member state foreign policies - in the sense of 'downloading' a harmonized world view and agenda is uneven, especially with expanded membership (Tonra, 2015).

EU difficulties pursuing a unified normative foreign policy have been sharpened by increasing internal security, economic and legitimacy challenges, and an increasingly volatile neighbourhood. The dream of the 'Arab Spring' advancing democracy became a nightmare with the destabilisation of the region. Following the associated wave of uncontrolled migration, and Jihadist attacks in European cities, the EU's 2016 Global Strategy emphasised the precedence of stability over democracy in Middle East policy (Roccu \& Voltolini, 2018).

Yet I argue here that these difficulties have catalysed another challenge to EU foreign policy unity: the proliferation of a European identity discourse that challenges the universalist concept of liberal values underpinning 'normative power Europe'.

Role theorists persuasively argue that 'role concepts provide us with an analytical and operational link between identity constructions and patterns of foreign policy behaviour' (Aggestam, 2004). According to March and Olsen (1998, p. 952), political actors are constituted by a subtle interplay between 'interests, by which they evaluate their expected consequences', and 'rules embedded in their identities and political institutions.' National role conceptions guide policy makers by providing patterns for internationally and domestically expected and appropriate responses to events.

Role conceptions are influenced by the expectations of other international actors', including institutions. Harnisch, Frank and Maull (2011, p. 254) attribute to EU institutions the capacity to socialise members to behave in line with the expectations of its normative agenda. According to Aggestam (2004, p. 91), 'The stability of the EU as a foreign policy actor ... is 
dependent on the member states modifying their behaviour according to each others' roles and expectations.'

However, role conceptions can vary between constituencies within a society (Cantir \& Kaarbo 2016; Breuning, 2011). They are also subject to constant reconstruction, catalysed by changes in structural conditions and leadership, and the presence of crisis (Gustavsson, 1999). Nabers (2011, p. 87) describes how competing discourses can contend to become the leading interpretative structure' within a society.

I argue that civilizationism challenges the EU normative consensus by representing a rival interpretative structure, framing Europe less as representing a universal, secular liberal creed to be promoted globally, and more as the bastion of a unique cultural heritage, to be defended from non-European cultures, especially Islam. As this alternative framing of European identity gains ground, it undermines the EU's capacity to socialise its members.

\section{The rise of 'Judeo-Christian civilizationism' in Europe}

Petito and Bettiza (2018) explain the prevalence of civilizational discourses guiding international actions as a consequence of globalization and associated uncertainties, which catalyse culturally focussed identity politics. Post-essentialist approaches to civilizational identity are 'sceptical of essentialist claims about civilizations ... but sensitive to the power that such claims exercise in social and political practice' (Hall \& Jackson, 2007, p. 4). They reject Huntington's (1996) claim that civilizations have relatively fixed characteristics, emphasising civilizations' internal contestations, only loose integration, and constant change. Katzenstein (2010, p. 12) argues that 'Making civilizations primordial is a political project that aims at creating a taken-for-granted sense of reality that helps in distinguishing between self and other and right and wrong.'

The civilizationist dimension in European political discourse has been increasing, including reference to the role of religion in shaping European political culture (Brubaker, 2017). The early 2000s debate about referring to Christianity or Judeo-Christianity in the EU constitution reflected an underlying tension. The decision against, along with Turkey becoming a candidate country despite strong opposition, symbolised the resilience of a norm that the EU was not defined by a particular faith or civilization.

The Barcelona 'Euromed' Process launched in 1995 was similarly premised on rejecting the Huntingtonian 'Clash of Civilizations'. It reflected not only the aspiration to expand free 
trade, but faith in the universality of the EU's values, and the enriching potential of cultural dialogue (De Perini, 2019). After 9/11, Europeans continued trying to frame 'the Mediterranean' as a geopolitical region transcending Western and Islamic Worlds (Adler, Bicchi, Crawford, \& Del Sarto, 2006).

This agenda has been undermined by a backlash against globalization, integration, and migration, exacerbated by the rising Jihadist threat, as well as the great recession. Radical right parties have risen, characterised by nativism, authoritarianism, and populism (Mudde, 2007). In Western Europe they have pulled centre-right conservative parties in their direction (Bale, 2003). Economic stagnation exacerbated transnational divides between the beneficiaries of globalization who identify as 'European', and those who feel disadvantaged, and seek the state's protection from globalization (Fligstein, 2008).

International concerns are important to radical right populists, especially globalization, denationalization, and immigration (Liang, 2007). Significant foreign policy orientations span many populist right parties, including support for sovereign nationalism and skepticism towards global governance and intervention. (Chryssogelos, 2017; Stengel, MacDonald, \& Nabers, 2019; Verbeek \& Zaslove, 2017)

An increasingly prominent unifying cry is the supposed Islamic threat to Europe's 'Western Judeo-Christian humanist culture' (Zuquete, 2008). Whilst images of Islam as antithetical to Europe run deep, this current political agenda developed in the 1990s, as Europeans grappled with integrating growing, settled Muslim minorities (Betz, 2007). Dutch politician Pim Fortuyn was a progenitor of a political agenda which casts 'backward' Islam as a threat to superior Western, secular modernity, rooted uniquely in Judaism, Christianity and humanism (Kluveld, 2016). Today a wider array of European 'Alarmists' warn that Islamic culture threatens European integrity (Joppke, 2014). This trend developed in parallel with a growing anti-Islamic theme among US Evangelicals and Conservatives, spurred in the 1980s and 1990s by the Iranian revolution and Jihadist threats culminating in 9/11 (Gerges, 1999). The notion of Islamic threat played a significant role in the 2016 Trump campaign.

Civilizationist discourses position the populist right as the defender not only of the nation but the wider civilization, against Islamic threats to its security, and no less importantly to its values. Mainstream political elites are accused of exposing Europe to 'Islamization' through multi-culturalism, migration and Turkish accession (Marzouki \& McDonnell, 2016). This 
ferment was accelerated by the wave of uncontrolled migration in 2015 and Merkel's decision to absorb new arrivals.

Until quite recently, anti-Semitism remained a common feature of the European populist radical right, alongside anti-Zionism and anti-Americanism (Liang, 2007, p. 25). Whilst it remains conspicuous in far-right parties such as Golden Dawn in Greece and Jobbik in Hungary, as anti-Islamic politics has evolved, a swathe of radical right parties have switched to expressing solidarity with Jews. As Brubaker (2017, p. 1202) has observed, where once the Jew was considered the threat to the ethnocultural integrity of the nation, 'in the broader comparative civilizational perspective of the new populism, Jews are redefined as fellow Europeans and as exemplary victims of the threat from Islam'. This redefinition of Jews as fellow Europeans serves the radical right a double purpose: constructing European identity in a manner that emphasises the exclusion of Muslims as the anti-European (and anti-Semitic) other; whilst distancing them from their own unattractive, anti-Semitic origins or associations (Hafez, 2014).

For the radical right, adopting 'Judeo-Christian' discourse in referring to the common cultural ground of Europe serves this agenda. There is broad awareness that, beginning in the 1990s, parts of the populist right increasingly invoked Europe's Christian roots in their objections to Muslim immigration. Hurd (2008) has astutely described the significance of what she calls 'Judeo-Christian secularism' - the notion that a Judeo-Christian tradition is the unique grounding for Western secularism - in implying that other cultures, and especially Islam, are inhospitable for democracy. But the specific political role of the 'Judeo' prefix has been less considered.

It is beyond our scope to assess the claim that a coherent set of Judeo-Christian values forms the consensus ground of Western political culture, suffice to say that 'Judeo-Christian' is far from an obvious and uncontroversial category. Where the label has gained currency, it has been more due to political utility than philosophical content. References to 'Judeo-Christian' grounding of Western liberal values by politicians developed in the US around World War II. The political intent was to include Jews in a shared civic identity, in contrast to anti-Semitic and godless European ideologies of Fascism and Communism (Strote, 2016). For the contemporary radical right in Europe the use has changed: the Judeo-Christian formula conveys that Judaism is part of a supposed, authentic European culture in a way that Islam, which by definition is not. 
Marine Le Pen declared in 2014: 'That a new religion has increasing demands that collide with the ... the ways of life ... of a country ... founded on Judeo-Christian values, that's a problem.' (Alduy, 2014) Nigel Farage responded to the January 2015 Paris attacks in the European Parliament by calling on Europeans to 'be a lot braver and a lot more courageous in standing up for our Judeo-Christian culture.' The AfD's 2016 manifesto declares its opposition to 'Islamic practice which is directed against our liberal-democratic constitutional order, our laws, and the Judeo-Christian and humanist foundations of our culture.'

In post-Communist Europe, populist-nationalism is different. Victor Orban frames 'Christian Democracy' as a defence of 'Christian' family values against secular libertarianism. Until recently, with no significant Muslim minorities, anti-Islamic rhetoric was hardly relevant. But since 2015 Orban has similarly reinforced his European Christian rhetoric with anti-Muslim layers, and talk of Europe's Christian roots morphs into talk of Jewish and Christian roots when contextually appropriate. When opening a reconstructed synagogue in Serbia in 2018, Orban referred to 'Europe which rests on the Jewish and Christian heritage,' and to 'regions to the south and east of us where our Jewish and Christian brothers and sisters are being persecuted' (Orban, 2018).

Having described the emergence of Judeo-Christian civilizationism in Europe, the next section highlights how this form of identity politics relates to the Israeli-Palestinian arena.

\section{Judeo-Christian civilizationism and the Israeli-Palestinian conflict}

In the expansive literature on the EU and the Israeli-Palestinian arena (Martins, 2015b), some key themes stand out. The issue has long tested the EU's ability to formulate a unified foreign policy (Musu, 2010). European attitudes are shaped by complex overlapping historical legacies, including Europe's Jewish question; colonialism; support for Israel in its early years; and - increasingly since 1967 - a leading role promoting Palestinian national rights and more recently Palestinian statehood.

EU diplomatic and bottom up support for Palestinian statehood are taken to illustrate both the EU's normative foreign policy ambition and potential (Bouris, 2014), but also its limitations (Pace, 2009). Widely noted is that Israel's exceptional integration with the EEA has advanced despite increasing EU frustration at Israeli policies in the Palestinian arena (Pardo \& Peters, 2010). Despite widespread concerns that Israeli policies, especially settlement construction, breach international law, compromise Palestinian rights, and undermine a two-state solution, there has been insufficient unity to apply conditionality to the deepening of EU-Israel 
relations in line with the 1995 Association Agreement and 2004 Action Plan. Trade agreements were signed covering agriculture in 2009 and pharmaceuticals in 2012, and a major aviation agreement in 2013.

States seeking a tougher line have helped ensure no EU-Israel Association Council has been held since 2012 to further advance bilateral ties. But since 2012, when the FAC declared that EU agreements must explicitly apply only to Israel's pre-1967 borders, there have also been no substantial Council measures to increase pressure over settlements. Attempts to expand the policy of differentiation between Israel and the Occupied Territories in ways that might harm Israeli businesses and banks were blocked in 2016 by supporters of Israel's government in the FAC, including Greece and Hungary (Lovatt, 2016).

Nor has there been enough unity to extend recognition to Palestine, despite several national parliaments and the European parliament backing it. Some states have consequently taken unilateral initiatives, such as Sweden's recognition of Palestine, and France's international conference to promote peace talks in 2017.

The differences between member states have been repeatedly exposed in UN General Assembly votes, defying the CFSP aspiration to a 'common approach' within international organizations (Keukeleire \& Delreux, 2014, p. 303). In the 2012 vote on upgrading Palestine's UN status to a non-member state, 14 EU members voted for, 12 abstained, and one opposed.

The Israeli-Palestinian issue has long spread EU members on a spectrum of positions, with divergences driven by interests, identity and domestic politics. Geopolitics is significant for France, as the leader of Mediterranean members promoting ties with southern neighbours and attempting to insert the EU into regional diplomacy (Bicchi, 2007). But 'like-minded' proPalestinian states also include Ireland and Sweden, whose political culture shapes a concern for international law and human-rights.

Meanwhile Holocaust responsibility is defining for Germany, and to a lesser extent Austria, and influential for other states whose Jewish communities were destroyed. The UK has tended to a balanced position, shaped by historic ties to Arab states, but also its relationship with Washington, and resistance to French competition with US diplomacy. Atlanticism is also significant for former Communist states, including Hungary, the Czech Republic and Poland. These now form the core of 'like-minded states' blocking increased pressure on Israel, even while concerns about anti-Semitism endure (Greene \& Rynhold, 2018). Israel's 
rising economic, military and technological capability, and Mediterranean energy resources, have made it an increasingly significant strategic ally for some - including Cyprus and Greece, with concerns about Erdogan's Turkey (Tziarras, 2016).

Aside from these national characteristics, Israel's own complex and contested identity has long engendered polarised perceptions in the West (Del Sarto, 2003; Greene, 2013). Whilst there is a broad consensus that both Jews and Palestinian have a legitimate right to selfdetermination, there is a significant right-left split. The right displays a greater tendency to identify with Israel not only as a legitimate expression of Jewish emancipation, and as a strategic ally against radical anti-Western forces, but as an outpost of Western democracy. By contrast, to the further left, there is a greater tendency to identity with Palestinian nationalism as an anti-colonial or anti-hegemonic movement, and view Israel as a racist ethnocracy, abuser of Palestinian rights, or agent of US neoimperialism.

Yet this picture of European attitudes needs updating in the light of rising civilizational politics. Before anti-Islamic politics became central for radical right parties, the dominant tendency in this party family was towards anti-Semitic anti-Zionism. Common tropes included conspiracy theories blaming Israel or global Jewry for manipulating US policy and global events, and attempts to discredit Israel with accusations of brutality (Liang, 2007, pp. 23-27).

Gradually however this has been displaced by pro-Zionism framed by Judeo-Christian civilizationism. A notable milestone came in 2010, when several European populist right leaders visited Israel, including then-FPÖ leader Hans Christian Strache, and representatives of Belgium's Vlaams Belang, the Swedish Democrats, and the short-lived German Freedom Party (Hafez, 2014). There they issued the 'Jerusalem Declaration', asserting their commitment to 'the canon and values of Western civilization, based on the spiritual heritage of Greco-Roman antiquity, Judeo-Christian cultural values, humanism and the enlightenment,' which was threatened by 'fundamentalist Islam'. They asserted that 'Israel is the only real democracy in the Middle East' and affirmed the 'right of Israel to self-defence ... against Islamic terror.' (“Jerusalemer Erklärung,” 2010)

This framing has adherents too in European centre-right parties. Also in 2010, former Spanish PM Jose Maria Aznar launched a Friends of Israel initiative backed by various retired politicians, whose manifesto declared: 'The assault on Israel is itself an assault on 
Judeo-Christian values. Israel stands on the front line, but we are next in line.' ("Stand for Israel, Stand for the West," 2010)

Together these two documents distil the central features of the Judeo-Christian civilizationist framing of the Israeli-Palestinian issue. In summary: Western values are rooted in a supposed 'Judeo-Christian' tradition and are threatened by the spread of Islamic fundamentalism. In that context, Israel is a civilizational kin state to Europe and the West, and indeed the frontier state of the Judeo-Christian world. Regional rejection of Israel is not because of its illegitimacy as a Western colonial imposition, or because of its actions, but because of its Western values. This Arab-Islamic rejectionism, and not the occupation, is the root of the Israeli-Palestinian conflict. By extension, Palestinian or Arab violence against Israel is not an expression of justified grievance, but inspired by anti-Western religious extremism. Therefore, the Jihadist threat to European security is analogous to, or on a continuum with, the threat posed to Israel by Islamist extremists. By the same token, pressuring Israel into territorial concessions or criticising its security policies is capitulation or appeasement in the face of Jihadist threats. It also has direct implications for Western security. Firstly, the misuse of 'human rights' claims and international legal tools by Israel's enemies to undermine its sovereign right to self-defence will similarly be used to delegitimise the security policies of other Western states. Secondly, Israel is a vital regional ally in containing global Jihadist movements, and weakening Israel undermines Europe's own security.

This narrative is particularly conspicuous when radical right politician address Israeli, Jewish, or US conservative audiences. Geert Wilders declared in a visit to Israel in 2010: 'Your country is the cradle of Western civilization. We call it the Judeo-Christian civilization with good reason' (Wilders, 2010). Czech president Milos Zeman declared in Israel in 2017: 'We are currently facing a major migration crisis associated with terrorism ... an incompatible culture of hatred is threatening the fundamental values of Judeo-Christian European culture ... Israel and its heroism is an inspiration for us' (Beck, 2017). Italian Lega Deputy Prime Minister Matteo Salvini declared in Jerusalem: 'Whoever wants peace needs to support Israel' (Ahren, 2018). Polish Law and Justice figurehead Jarosław Kaczyński described Israel in 2017 as the 'frontier embassy of our [Western] civilization ... the most humane civilization that has ever existed' (Adekoya, 2018). 
This framing resonates with the dominant claims of the Israeli right, that the root of the conflict is Islamic extremism and Palestinian rejection of Jewish rights, to which the occupation is peripheral.

The admiration for Israel is no doubt aided by the perception of the country as an economically successful, ethnically rooted and militaristic sovereign state, capable of using force to defend itself, and unencumbered by EU membership.

But does this framing of the Israeli-Palestinian conflict in civilizationist terms impact policy preferences among EU governments? In the following section I assess the case of Austria, which saw in December 2017 the formation of a coalition between the conservative ÖVP and radical right FPÖ. Austria is an apt case for several reasons. Firstly, the shift from a centrist SPÖ-ÖVP coalition under an SPÖ Chancellor, to an ÖVP-FPÖ coalition under an ÖVP Chancellor, allows an evaluation of the significance of party-political change. The material factors - economic and security ties; geography; demography - all remained fixed, but the decision makers changed along with the parties, constituencies and ideologies they represent. Secondly, the FPÖ, as one of the most long-standing radical right parties in Europe, with notable anti-Semitic roots, exemplifies the adoption of Judeo-Christian civilizationism as anti-Islamic politics has gained prominence. The fact that it served in a similar coalition in the early 2000 s provides a point of comparison to evaluate change on the radical right over this period. Whilst the generalizable conclusions to be drawn from a single case study are limited, the case highlights issues which can be explored in future studies incorporating more cases.

The case study provides a general background to Austrian foreign policy identity and role, and factors shaping attitudes towards the Israeli-Palestinian arena, before evaluating how Austrian policy orientations were impacted by the new coalition. The case study then goes beyond the existing public record by presenting new evidence on the motivations of the actors from in-depth interviews conducted by the author with senior officials and politicians directly involved. These include coalition foreign minister Karin Kneissl, Austrian ambassador to Israel Martin Weiss, and ÖVP parliamentarian and Jewish community member Martin Engelberg. 


\section{The Austrian case}

Though Austria has no especially pronounced interest in the Israeli-Palestinian arena, as with every EU member, it has its nexus of ideational and interest based factors shaping its orientation.

Austria's foreign policy has evolved in phases since 1945. The end of occupation in 1955 was premised on its commitment to neutrality. Under the influence of Bruno Kreisky as SPÖ foreign minister (1959-1966) and chancellor (1970-1983), Austria played mediator between the US-led West and Soviet East. Kreisky extended Austria's 'active neutrality' to the Middle East, including as an early advocate for PLO recognition (Secher, 1994). This left a legacy for Austrian diplomats and the SPÖ of a supportive attitude towards Palestinian aspirations. Kreisky - despite Jewish origins - also typified Austrian resistance to share responsibility for Nazi crimes. He engaged in angry clashes with Austrian Nazi hunter Simon Wiesenthal, who exposed the war records of his cabinet members.

In the 1980s Austrians re-examined their past. Their national narrative as 'first victims' of Nazism was reconsidered, triggered by the 1986 controversy over presidential candidate Kurt Waldheim's war record (Pelinka, 1998, p. 192). The affair put new scrutiny on Austria's past, but also exposed enduring anti-Semitic attitudes (Reiter, 2013). In 1993, Chancellor Franz Vranitzky acknowledged Austrian co-responsibility for the Holocaust, including during a visit to Israel.

Joining the EU in 1995 reinforced the decline of Austria's 'active neutrality' concept shaping its foreign policy role conception. With some exceptions (notably the Balkans) Austria shifted to relative disinterest and anonymity, as it acquiesced to integration of its global role with the multilateral structures of the EU, dominated by larger states. Two decades after accession, Muller and Maurer (2016) wrote that, 'Austria has displayed little interest to develop an active foreign policy profile.'

The entry of the FPÖ under Jörg Haider into a coalition led by ÖVP Chancellor Wolfgang Schüssel in 2000 temporarily added notoriety to Austria's profile. The coalition shocked other EU members, triggering temporary sanctions, and further detracting from Austria's international influence. The FPÖ was founded by former Nazi officers in the 1950s, and rooted in pan-German nationalism with its attendant anti-Semitism. Haider, the son of Nazis, was reluctant to condemn his parents' generation (W. C. Müller, 2000, p. 198). 
Haider's participation in the Austrian government led to the withdrawal of Israel's ambassador. Under Haider, FPÖ foreign policy swung from opposing neutrality and supporting NATO during the Cold War, to anti-Americanism after the Cold War (Chryssogelos, 2015). The dominant trend in the early 2000s was anti-American and antiZionist. Haider showed fascination for Saddam Hussein, visiting him twice in 2002. In the FPÖ-aligned Aula magazine, Israel and the Jews were accused of acting like Nazis towards Palestinians, of controlling the US, and of causing terrorism (Virchow, 2007). A 2008 FPÖ party document condemned: 'the aggressive repressive politics of Israel against the Palestinians' (Meret, 2010, p. 207). In June 2010, the FPÖ backed a resolution in the Vienna City Council condemning Israel over the interdiction of the Mavi Marmara (Weinthal, 2010).

How does this compare to the FPÖ during the 2017-2019 coalition? By 2017 the party had undergone a stark U-turn. Austria has been increasingly impacted by rising anti-Islamic, antiimmigration, and anti-integration sentiment, on which the FPÖ has capitalised. Already in 1997, the FPÖ, traditionally anti-clerical, inserted references in its programme to Christianity's importance in Western values (Luther, 2010). Strache, who led the party from 2005 had initially opposed this (Hadj-Abdou, 2016, p. 35). However, as leader he embraced religious symbolism amid growing public concern at the expanding Muslim minority, famously brandishing a cross whilst demonstrating against construction of a mosque (Wodak, 2015, p. 140). He also publicly denounced anti-Semitism, though this endeavour was harmed by anti-Semitic incidences among activists, including an anti-Semitic cartoon posted on Facebook by Strache himself in 2012 (Stoegner, 2016).

In the context of his efforts to detoxify his party, in late 2010 Strache signalled a sharp shift on Israel, by participating in the visit that generated the aforementioned 'Jerusalem Declaration'. He visited Israel again in 2016, and declared: 'I always say, if one defines the Judeo-Christian West, then Israel represents a kind of border. If Israel fails, Europe fails. And if Europe fails, Israel fails' (Baker, 2016). Undeterred by the Netanyahu government maintaining its non-contact policy with the FPÖ, Strache, still in opposition, wrote to Netanyahu in 2017 to celebrate the $50^{\text {th }}$ anniversary of Jerusalem's reunification. He committed to 'take upon myself to do all in my power ... to move the Austrian Embassy ... to Jerusalem', and declared: 'the State of Israel possess the right to build wherever is required in the Land of Israel.' (Ahren, 2017) 
His coalition partner, ÖVP Chancellor Sebastian Kurz, also positioned himself as warm towards Israel as foreign minister (2013-2017), and had several meetings with Netanyahu. Kurz, born in the early 1980s and socialised in the period of Austria's re-examination of its past, tended to frame support for Israel in terms of Austria's moral responsibility for Israeli and Jewish welfare.

At the same time, ÖVP is a centre-right party rooted in Catholicism and conservatism. Kurz found electoral success in 2017 by talking tough on immigration (Bodlos \& Plescia, 2018). Kurz also highlighted his Catholic faith, and engaged in civilizationist discourse during his campaign and subsequently, declaring: 'We have a culture shaped by our Judeo-Christian heritage and the Enlightenment - and this culture needs protecting, especially at a time of high and rising immigration' (Johnson, 2017).

How did this coalition shape Austrian policy in the Israeli-Palestinian arena? After the formation of the ÖVP-FPÖ coalition in December 2017, the low-profile approach to foreign affairs gave way to new assertiveness. In December 2018 Austria was one of eleven EU members to reject the UN Global Compact on Migration, despite the Commission having played an active role in promoting the project and its human rights centred approach, in line with the EU's normative agenda (Apap, Diaz, \& Trevino, 2019).

An equally conspicuous shift was evident in the Israeli-Palestinian arena. The previous SPÖ ÖVP coalition expressed responsibility for Jewish and Israeli welfare, but when faced with EU divisions on the Israeli-Palestinian arena, leant towards Palestinian preferences. On upgrading Palestine to a non-member state in the UN in 2012, Austria was one of $14 \mathrm{EU}$ members to vote in favour. Austria was one of 13 states in 2013, and 16 states in 2015, to sign a letter calling on the EU High Representative to issue guidance on labelling goods from Israeli settlements (Ravid, 2015).

The new coalition brought a significant shift. On his first day in office Kurz met the Israeli Ambassador in Vienna and told her he respected the Israeli government decision not to engage with FPÖ ministers (Landau, 2017). The ÖVP-FPÖ government then unusually included in the government program a direct commitment to Israel 'as a Jewish state' and 'a peaceful solution in the Middle East, with particular attention to the security interests of Israel.' (Zusammen. Für unser Österreich. Regierungsprogramm 2017 - 2022, 2017). These are formulations that, according to Austrian ambassador to Israel Martin Weiss, 'no other government has used and would have used.' Weiss added, 'It was meant as a political signal 
because of the presence of FPÖ in the coalition, but it also shows that both parties could agree on Israel' (M. Weiss, personal communication, June 20, 2018).

In a February 2018 meeting in Jerusalem, Kurz not only reiterated Austria's 'special responsibility towards Israel and the Jewish people' and promised to 'raise awareness in Europe for ... the special security needs of Israel', but also promised Netanyahu a shift in Austria's UN voting, and backing for Israel's Security Council candidacy (Landau, 2018).

Just three days after the ÖVP-FPÖ government was formed in December 2017, Austria had voted with 22 out of $28 \mathrm{EU}$ member states to condemn the US recognition of Jerusalem as Israel's capital. However, according to Ambassador Weiss, 'It was in the very early stages of the government, and if there had been more time to look at it, it might have been that we would have landed on the side of the six [EU members that abstained from the resolution].' (M. Weiss, personal communication, June 13, 2018). In May 2018, Austria signified this shift and moved decisively out of the EU mainstream, by being one of just four EU member states to send representation to the opening of the new embassy, alongside the Czech Republic, Hungary and Romania. This was an illustration of individual member state positions undermining the EU's capacity to unify its diplomatic stance.

Then, for the first time in a split EU vote in UNGA, also in May 2018, on a resolution condemning Israeli actions on the Israel-Gaza border resulting in Gazan civilians deaths, Austria leant towards Israeli preferences and abstained (as one of 16 EU members including Germany), rather than voting yes with France.

Ambassador Weiss, when asked how he would position Austria in the spectrum of positions on the Israeli-Palestinian issue, replied:

We used to be towards the left of that spectrum, closer to Palestinian concerns and more critical of the Israeli position. I think we moved towards the middle of this group and with this new government we moved towards the right, meaning more understanding of Israeli actions, and not really willing to give Israel constant advice about how they should run their affairs (M. Weiss, personal communication, June 13, 2018).

The shift in orientation that came with the new coalition is therefore clear. But what explains it? Those involved in the coalition policy give explanations with resonate with elements of the civilizationist world view. 
Martin Engelberg, a member of the Austrian Jewish community recruited by Kurz as an ÖVP candidate, who accompanied the Chancellor on his 2018 visit to Israel, highlighted the contrast between Kurz and German Chancellor Angela Merkel:

Chancellor Kurz is ... part of a new generation of politicians - I call it the post Merkel era. The Merkel era is where Germany finally regained some moral rehabilitation with letting refugees in. The post-Merkel era is being more realistic about the problems we brought in here, and the future of Europe, and really keeping these Western Judeo-Christian values. If you heard the statements of prime minister Netanyahu and the Chancellor, we are speaking about establishing a strategic relationship between not only Israel and Austria but between Israel and the Union (M. Engelberg, personal communication, June 20, 2018).

Ambassador Weiss, when asked to explain this shift, pointed to the long term significance of the younger generation accepting Austrian co-responsibility for the Holocaust and not influenced by the anti-Semitic attitudes. But he then identified 2015 as a turning point.

More than $1.5 \mathrm{~m}$ refugees crossed Austrian territory and the government was basically throwing up their hands and saying 'well there is nothing we can do' there was a feeling of total loss of control ... which is part of the reason why we have the government we have now. Because they were taking the line: 'We have to be strong, we have to protect our borders, if need be force will have to be applied.' And in that context Israel also looks much better because you say, 'Look how they protect their border'. We had a number of Austrian politicians who came to Israel and went to the Sinai to see how you build a decent fence (M. Weiss, personal communication, June 13, 2018).

The political crisis affecting the region also highlighted the strategic significance of Israel as a prop of stability for its Arab neighbours threatened by Islamist extremism. According to Weiss, 'Israel would say "listen guys if tomorrow Egypt goes down in a violent domestic clash, where do you think the political refugees will go ... they would rather go to Europe. So if we help Egypt, it is not only good for Israel, but it's also good for you guys." And I think people buy that argument' (M. Weiss, personal communication, June 13, 2018).

The coalition's foreign minister was Karin Kneissl, an academic with specialist knowledge of the Middle East, nominated by (though not a member of) the FPÖ. When asked what trajectory she saw in attitudes towards Israel and the Israeli-Palestinian arena, she responded: 
The year 2015 was a watershed line ... when we had this massive immigration from Middle East; when we had a rise in terror attacks in Europe ... I would say the overall perception of Israel and how Israel is dealing with Hamas for instance, has changed ... And this is something that is encapsulated ... in how certain politicians in Austria see Israel, as a role model. How do you handle terrorism and how do you continue normal life despite terrorist threats ... I would say there was a growing understanding (K. Kneissl, personal communication, June 22, 2018).

Opponents and analysts outside the coalition interpreted the support for the Israeli government policy in more instrumentalist terms. Opposition SPÖ Nationalrat member and development affairs spokesperson Petra Bayr, dismissed the government's pro-Israel policy as 'blue washing' - showing warmth to Israel to address suspicions of anti-Semitism. According to Bayr this is primarily to communicate to a domestic audience the message that: 'they will not say any anti-Semitic or anti-Israel things so don't worry' (P. Bayr, personal communication, June 19, 2018).

Leading Austrian political historian Oliver Rathkolb viewed the political audience to be not only domestic but also European. It reflects according to Rathkolb, a 'learning process' from the difficult experience of Schüssel in 2000. The need of Kurz and Strache to address concerns about the FPÖ remains relevant against the backdrop of recurring incidences of anti-Semitism among its ranks (Stoegner, 2016). According to Rathkolb, '[Kurz] wants a clear statement to both the EU and the Austrian public that ... the Austrian government is not moving back in history, and vice chancellor Strache is doing the same.' (O. Rathkolb, personal communication, June 20, 2018).

In sum, what does this evidence tell us? Austria's shift to a more supportive position toward Israel is a long-term trend rooted in changes in Austrian political culture that began in the 1980s with acknowledging co-responsibility for the Holocaust and a much greater sensitivity to anti-Semitism. From the late 1990s the FPÖ adopted religio-cultural symbolism as it focussed on opposition to the growing Muslim minority, though under Haider, the party remained hostile to Israel. As Strache sought to detoxify the party domestically and internationally, he made an abrupt shift in around 2010 to transform FPÖ from an anti-Zionist to a pro-Israel party, and picked up the burgeoning notion of Europe as 'Judeo-Christian' in his pro-Israel rhetoric. 
This created an alignment with his conservative coalition partner Kurz, who was committed to Austrian moral responsibility for Israel's welfare and keen to avoid the opprobrium that faced the Schüssel-Haider government; and simultaneously ready to confront the EU mainstream on migration and talk up the Judeo-Christian cultural roots of Europe.

Austrian attitudes towards Israel were also impacted by changes in the Middle East. The postArab Spring destabilization, which triggered uncontrolled migration through Austria, reinforced the image of Israel as a model and ally in the struggle with Islamist extremist violence, and increasingly important prop of stability for Egypt and Jordan in particular.

However, whilst that crisis peaked in 2015, it was the 2017 formation of the ÖVP-FPÖ coalition that marked a shift in Austrian diplomatic alignment. In explaining the shift, there is no simple way to disentangle identity, interests and rhetoric. The shifting role conception of Austria, in the context of the increasing tendency to identity Europe in terms of supposed Judeo-Christian values threatened by Islam, is interwoven with a complex set of domestic and international political motivations. What can be said is that for the FPÖ in particular, the notion of Europe as a 'Judeo-Christian civilization' provided a rhetorical and conceptual framework for their swing from the anti-Zionism evident under Haider's leadership, to fervent support for the Netanyahu government under Strache.

\section{Conclusion}

The adoption of religious imagery and language by many populist radical right parties to emphasise a civilizational divide with Islam, has converged with an agenda to detoxify themselves from anti-Semitic associations, leading to increasing references to Europe as 'Judeo-Christian'. In this rhetorical and cognitive framing of Europe's identity, Israel is depicted as the frontier state of Western Judeo-Christian civilization.

The abruptness of this turn on the radical right, as illustrated in the Austrian case, implies not a deep philosophical reconsideration of Judaism's contribution to European culture, but rather the political utility of the shift. The morphing between references to the 'Christian' roots of Europe to the 'Judeo-Christian' roots offers a powerful illustration of the how civilizational identities, far from being primordial, mould around political agendas.

Whilst the focus here has been on the Judeo-Christian construction and the Israeli-Palestinian arena, attention should be paid to how civilizationist discourses shape an alternative 
conception European identity and role, and the significance for EU foreign policy more broadly.

As civilizationist identity becomes embossed in the patterns of discourse and cognitive framing of leaders on the European right, it challenges the EU's dominant universalist and human rights centred identity and role conception. This latter approach will not be easily displaced, being deeply embedded in EU institutions and treaties. However, the stronger the presence of the civilizationist rival, the more it will inhibit the EU's ability to download its normative agenda, and shape a unified foreign policy among its members.

To point to another example, in responding to the Syrian civil war, radical right parties have consistently criticised the mainstream approach of isolating Assad on human rights grounds. They have called instead to align with Assad and his Russian backers in the fight against Islamic extremism, and to stabilise the sovereign Syrian government in order to prevent mass migration, and ultimately to facilitate the return of migrants who threaten both European security and cultural identity.

To understand diverging foreign policy preferences among EU members we must examine not only the shifting nexus of interests, world views and political identities of each set of decision makers, but also the increasing significance of civilizationist interpretations of European identity. This insight prompts further case study research in a range of countries and variety of issues into the extent to which contrasting conceptions of European identity produce competing role conceptions, and impact the quest for a unified European foreign policy. 


\section{References}

Adekoya, R. (2018, February). Poland's Holocaust Denialism Will Come Back to Haunt It. Retrieved July 15, 2019. Foreign Policy. Retrieved from https://foreignpolicy.com

Adler, E., Bicchi, F., Crawford, B., \& Del Sarto, R. A. (2006). The convergence of civilizations: constructing a Mediterranean region. Toronto: University of Toronto Press.

Aggestam, L. (2004). Role identity and the Europeanisation of foreign policy: a politicalcultural approach. In B. Tonra \& T. Christiansen (Eds.), Rethinking European Union Foreign Policy (pp. 81-98). Manchester: Manchester University Press.

Aggestam, L. (2008). Introduction: ethical power Europe? International Affairs, 84(1), 1-11.

Ahren, R. (2017, October 11). In Austria, rise of pro-Israel, far-right faction forces Israel into corner. Retrieved May 5, 2019. Times of Israel. Retrieved from https://www.timesofisrael.com

Ahren, R. (2018, December 12). Hosting Italy's deputy PM, Netanyahu urges stronger action against Hezbollah. Retrieved March 20, 2019. Times of Israel. Retrieved from https://www.timesofisrael.com

Alduy, C. (2014, March 5). Has Marine Le Pen Already Won the Battle for the Soul of France? The Nation. Retrieved from https://www.thenation.com

Apap, J., Diaz, D. A., \& Trevino, G. U. (2019, January). A global compact on migration. European Parliament Research Service. Retrieved from https://www.europarl.europa.eu/

Baker, R. (2016, April 12). "Far-right Austrian leader visits Israel's Holocaust memorial.” Reuters. Retrieved from https://www.reuters.com

Bale, T. (2003). Cinderella and Her Ugly Sisters: The Mainstream and Extreme Right in Europe's Bipolarising Party Systems. West European Politics, 26(3), 67-90.

Beck, E. (2017, December 22). "Israel is an inspiration.” Israel Hayom. Retrieved from http://www.israelhayom.com.

Bettiza, G., \& Petito, F. (2018). Why (Clash of) Civilizations Discourses Just Won’t Go 
The Version of Record of this manuscript is available in Mediterranean Politics (Published online: 29 March 2020). http://www.tandfonline.com/10.1080/13629395.2020.1739928

Away? Understanding the Civilizational Politics of Our Times. In D. Orsi (Ed.), The 'Clash of Civilizations' 25 Years On: A Multidisciplinary Appraisal (pp. 37-51). Bristol: E-International Relations Publishing.

Betz, H.-G. (2007). Against the "green totalitarianism": Anti-Islamic nativism in contemporary radical right-wing populism in Western Europe. In C. S. Liang (Ed.), Europe for the Europeans: the foreign and security policy of the populist radical right (pp. 33-54). London \& NY: Routledge.

Bicchi, F. (2007). European foreign policy making toward the Mediterranean. London: Palgrave Macmillan.

Bodlos, A., \& Plescia, C. (2018). Austrian snap election: a shift rightward. West European Politics, 41(6), 1354-1363.

Bouris, D. (2014). The European Union and Occupied Palestinian Territories: state-building without a state. Abingdon: Routledge.

Breuning, M. (2011). Role theory research in international relations: state of the art and blind spots. In S. Harnisch, C. Frank, \& H. W. Maull (Eds.), Role Theory in International Relations: Approaches and analyses (pp. 32-51). London \& NY: Routledge.

Brubaker, R. (2017). Between nationalism and civilizationism: the European populist moment in comparative perspective. Ethnic and Racial Studies, 40(8), 1466-4356.

Cantir, C., \& Kaarbo, J. (2016). Domestic role contestation, foreign policy, and international relations. New York \& London: Routledge.

Chryssogelos, A. (2015). Reaction and adaptation in the longue durée: the far-right, international politics and the state in historical perspective. In R. Saull, A. Anievas, N. Davidson, \& A. Fabry (Eds.), The Longue Durée of the Far-Right: An International Historical Sociology (pp. 85-105). New York: Routledge.

Chryssogelos, A. (2017). Populism in Foreign Policy. Oxford Research Encyclopedia of Politics. Retrieved from https://doi.org/10.1093/acrefore/9780190228637.013.467

De Perini, P. (2019). The changing scope of intercultural dialogue in EU Mediterranean policy. Mediterranean Politics. Advanced online publication. https://doi.org/10.1080/13629395.2019.1605757 
The Version of Record of this manuscript is available in Mediterranean Politics (Published online: 29 March 2020). http://www.tandfonline.com/10.1080/13629395.2020.1739928

Del Sarto, R. A. (2003). Israel's Contested Identity and the Mediterranean. Mediterranean Politics, 8(1), 27-58.

Diez, T. (2005). Constructing the Self and Changing Others: Reconsidering `Normative Power Europe'. Millennium: Journal of International Studies, 33(3), 613-636.

Fligstein, N. (2008). Euroclash: the EU, European identity, and the future of Europe. Oxon: Oxford University Press.

Gerges, F. A. (1999). America and Political Islam: Clash of Cultures or Clash of Interests? Cambridge: Cambridge University Press.

Greene, T. (2013). Blair, Labour, and Palestine: Conflicting Views on Middle East Peace After 9/11. New York: Bloomsbury Academic.

Greene, T., \& Rynhold, J. (2018). Europe and Israel: Between Conflict and Cooperation. Survival, 60(4), 91-112.

Gustavsson, J. (1999). How Should We Study Foreign Policy Change? Cooperation and Conflict, 34(1), 73-95.

Hadj-Abdou, L. (2016). The "religious conversion" of the Austrian Freedom Party. In Saving the People: How Populists Hijack Religion (pp. 29-47). London: Hurst \& Company.

Hafez, F. (2014). Shifting borders: Islamophobia as common ground for building panEuropean right-wing unity. Patterns of Prejudice, 48(5), 479-499.

Hall, M., \& Jackson, P. T. (2007). Introduction: Civilizations and International Relations History. In M. Hall \& P. T. Jackson (Eds.), Civilizational Identity: The Production and Reproduction of "Civilizations" in International Relations (pp. 1-12). New York: Palgrave MacMillan.

Harnisch, S., Frank, C., \& Maull, H. (2011). Role theory in international relations: approaches and analyses. London \& NY: Routledge.

Hill, C., \& Wallace, W. (1996). Introduction: Actors and actions. In Hill, C, (Ed.), The Actors in Europe's Foreign Policy, pp. 1-16. London: Routledge.

Huntington, S. P. (1996). The Clash of Civilizations and the Remaking of World Order. London: Simon \& Schuster.

Hurd, E. S. (2008). The politics of secularism in international relations. Princeton: Princeton 
University Press.

Jerusalemer Erklärung. (2010, December 7). Die Presse. Retrieved from:

https://diepresse.com/home/politik/innenpolitik/616660/Jerusalemer-Erklaerung-gegenIslamismus-im-Wortlaut

Johnson, B. (2017, December 4). What you need to know about the world's youngest ruler. Acton Institute. Retrieved from https://blog.acton.org/archives/99249-what-you-need-toknow-about-the-worlds-youngest-ruler.html

Joppke, C. (2014). Europe and Islam: Alarmists, Victimists, and Integration by Law. West European Politics, 37(6), 1314-1335.

Katzenstein, P. J. (2010). A world of plural and pluralist civilizations: multiple actors, traditions, and practices. In P. J. Katzenstein (Ed.), Civilizations in world politics: plural and pluralist perspectives (p. 236). Oxon: Routledge.

Keukeleire, S., \& Delreux, T. (2014). The Foreign Policy of the European Union. Basingstoke: Palgrave Macmillan.

Kluveld, A. (2016). Secular, Superior and, Desperately Searching for Its Soul: The Confusing Political-Cultural References to a Judeo-Christian Europe in the Twenty-First Century. In Nathan, E. \& Topolski, A. (Eds.), Is there a Judeo-Christian Tradition: A European Perspective. Berlin: De Gruyten.

Landau, N. (2017, December 19). Austria's chancellor: “I fully respect” Israel's decision to boycott new far-right ministers. Haaretz. Retrieved from https://www.haaretz.com.

Landau, N. (2018, February 16). For first time since Israel boycotts far-right party, Netanyahu meets Austria's Kurz, diplomats confirm. Haaretz. Retrieved from https://www.haaretz.com.

Liang, C. S. (2007). Europe for the Europeans: the foreign and security policy of the populist radical right. In C. S. Liang (Ed.), Europe for the Europeans: the foreign and security policy of the populist radical right (pp. 1-32). London: Routledge.

Lovatt, H. (2016, October 31). EU differentiation and the push for peace in Israel-Palestine. European Council on Foreign Relations. Retrieved from https://www.ecfr.eu/publications/summary/eu_differentiation_and_the_push_for_peace_ in_israel_palestine7163. 
The Version of Record of this manuscript is available in Mediterranean Politics (Published online: 29 March 2020). http://www.tandfonline.com/10.1080/13629395.2020.1739928

Luther, K. R. (2010). Governing with Right-Wing Populists and Managing the Consequences: Schussel and the FPO. In The Schussel era in Austria. New Orleans: University of New Orleans Press.

March, J. G., \& Olsen, J. P. (1998). The Institutional Dynamics of International Political Orders. International Organization, 54(4), 943-969.

Martins, B. O. (2015). EU-Israel Relations: Expanding the Research Agenda. In K. E. Jorgensen, A. K. Aarstad, E. Drieskens, K. Laatikainen, \& B. Tonra (Eds.), The SAGE Handbook of European Foreign Policy (pp. 659-673).

Marzouki, N., \& McDonnell, D. (2016). Populism and Religion. In Saving the People: How Populists Hijack Religion (pp. 1-12). London: Hurst \& Company.

Meret, S. (2010). The Danish People's Party, the Italian Northern League and the Austrian Freedom Party in a Comparative Perspective: Party Ideology and Electoral Support (Doctoral dissertation). Retrieved from https://vbn.aau.dk/ws/portalfiles/portal/20049801/spirit_phd_series_25.pdf

Mudde, C. (2007). Populist radical right parties in Europe. Cambridge: Cambridge University Press.

Müller, P., \& Maurer, H. (2016). Austrian foreign policy and 20 years of EU membership: opportunities and constraints. Österreichische Zeitschrift Für Politikwissenschaft, 45(2).

Müller, W. C. (2000). The Austrian election of October 1999: A shift to the right. West European Politics, 23(3), 191-200.

Musu, C. (2010). European Union policy towards the Arab-Israeli peace process: the quicksands of politics. London: Palgrave Macmillan.

Nabers, D. (2011). Identity and role change in international politics. In S. Harnisch, C. Frank, $\&$ H. W. Maull (Eds.), Role Theory in International Relations: Approaches and analyses (pp. 90-108). London \& NY: Routledge.

Orban, V. (2018). Speech at the inauguration of the renovated synagogue in Subotica, 26 March 2018. Retrieved from http://www.miniszterelnok.hu/viktor-orbans-speech-at-theinauguration-of-the-renovated-synagogue-in-subotica-szabadka/

Pace, M. (2009). Paradoxes and contradictions in EU democracy promotion in the 
The Version of Record of this manuscript is available in Mediterranean Politics (Published online: 29 March 2020). http://www.tandfonline.com/10.1080/13629395.2020.1739928

Mediterranean: the limits of EU normative power. Democratization, 16(1), 39-58.

Pardo, S., \& Peters, J. (2010). Uneasy neighbors: Israel and the European Union. Lanham, Maryland: Lexington Books.

Pelinka, A. (1998). Austria: out of the shadow of the past. Boulder, Col.: Westview Press.

Ravid, B. (2015, April 16). European FMs urge policy chief: Label West Bank settlement products. Haaretz. Retrieved from https://www.haaretz.com.

Reiter, M. (2013). Antisemitism in Austria after the Shoah. Judisches Museum Berlin. Retrieved from https://www.jmberlin.de/sites/default/files/antisemitism-in-europetoday_13-reiter.pdf.

Risse, T. (2010). A community of Europeans. New York: Cornell University Press.

Roccu, R., \& Voltolini, B. (2018). Framing and reframing the EU's engagement with the Mediterranean: Examining the security-stability nexus before and after the Arab uprisings. Mediterranean Politics, 23(1), 1-22.

Secher, H. P. (1994). Kreisky and the Jews. In G. Bischof \& A. Pelinka (Eds.), The Kreisky Era in Austria (pp. 10-31). New Brunswick, NJ: Transaction Publishers.

Smith, K. E. (2014). European Union Foreign Policy in a Changing World (3rd ed.). Cambridge: Polity Press.

Stand for Israel, Stand for the West. (2010, May 31). Friends of Israel Initiative. Retrieved from http://www.friendsofisraelinitiative.org/about/stand-for-israel-stand-for-the-west.

Stengel, F. A., MacDonald, D. B., \& Nabers, D. (2019). Introduction: Analyzing the Nexus Between Populism and International Relations. In Populism and World Politics (pp. 122).

Stoegner, K. (2016). 'We are the new Jews!' and 'The Jewish Lobby' - antisemitism and the construction of a national identity by the Austrian Freedom Party. Nations and Nationalism, 22(3), 484-504.

Strote, N. B. (2016). Sources of Christian-Jewish Cooperation in Early Cold War Germany. In Emmanuel Nathan \& Anya Topolski (Eds.), Is there a Judeo-Christian Tradition: A European Perspective. De Gruyter.

Tonra, B. (2015). Europeanization. In K. E. Jorgensen, A. K. Aarstad, E. Drieskens, K. 
The Version of Record of this manuscript is available in Mediterranean Politics (Published online: 29 March 2020). http://www.tandfonline.com/10.1080/13629395.2020.1739928

Laatikainen, \& B. Tonra (Eds.), SAGE Handbook of European Foreign Policy (pp. 183196). London: SAGE.

Tziarras, Z. (2016). Israel-Cyprus-Greece: a ‘Comfortable’ Quasi-Alliance. Mediterranean Politics, 21(3), 407-427.

Verbeek, B., \& Zaslove, A. (2017). Populism and Foreign Policy. In C. R. Kaltwasser, P. Taggart, P. O. Espejo, \& P. Ostiguy (Eds.), The Oxford Handbook of Populism (Vol. 1). Oxon: Oxford University Press.

Virchow, F. (2007). The Aims and Objectives of the Austrian Far Right in Foreign and Military Policies. In C. S. Liang (Ed.), Europe for the Europeans: the foreign and security policy of the populist radical right (pp. 55-80). London \& NY: Ashgate Publishing.

Weinthal, B. (2010, June 15). Austrian chancellor slams Vienna's anti-Israel resolution. Jerusalem Post. Retrieved from https://www.jpost.com

Wilders, G. (2010, December 5). Speech in Tel Aviv. Retrieved from https://www.pvv.nl/36fj-related/geert-wilders/3752-speech-geert-wilders-tel-aviv-5-december-2010.html Wodak, R. (2015). The politics of fear: what right-wing populist discourses mean. London: Sage Publications.

Wolff, S. (2018). EU religious engagement in the Southern Mediterranean: Much ado about nothing? Mediterranean Politics, 23(1), 161-181.

Zuquete, J. P. (2008). The European extreme-right and Islam: New directions? Journal of Political Ideologies, 13(3), 321-344.

Zusammen. Für unser Österreich. Regierungsprogramm 2017 - 2022. (2017). Retrieved from https://www.dieneuevolkspartei.at/download/Regierungsprogramm.pdf. 